\title{
LEADERSHIP IN ACTS THROUGH A SOCIAL CAPITAL LENS
}

Author:

Ian A. Nell ${ }^{1}$

\section{Affiliation:}

${ }^{1}$ Department of Practical Theology and Missiology, University of Stellenbosch, South Africa

\section{Correspondence to:}

Ian Nell

e-mail:

ianell@sun.ac.za

\section{Postal address:}

171 Dorp Street, Faculty of Theology, Stellenbosch, 7600, South Africa

\section{Keywords:}

leadership; Acts; social capital; faith communities; post-apartheid South Africa

\section{Dates:}

Received: 25 Aug. 2009 Accepted: 04 Nov. 2009

Published: 14 Dec. 2009

How to cite this article: Nell, I.A., 2009, 'Leadership in Acts through a social capital lens', Verbum et Ecclesia 30(2), Art. \#87, 7 pages. DOI: $10.4102 /$ ve.v30i2.87

\section{This article is available} at: http://www.ve.org.za

Note:

This article was previously delivered as a paper at the Acts conference, 'Missionary Church in Acts? A joint project of the Faculty of Theology of Stellenbosch and Communitas', 18-20 May 2009. This material is based on work supported by the National Research Foundation under Grant number 65620. Any opinions, findings, conclusions or recommendations expressed in this material are those of the author and the NRF does not accept any liability in regard thereto.

(c) 2009. The Authors. Licensee: OpenJournals Publishing. This work is licensed under the Creative Commons Attribution License.

\section{ABSTRACT}

Social capital can be defined in various ways. In most of these definitions at least three dimensions can be distinguished. First there is 'bonding' (the horizontal relationships between people operating within different social networks and with specific norms and values). The second dimension is 'bridging' (bonds that transcend differences in religion, ethnicity, culture and socioeconomic status). This dimension prevents horizontal ties from becoming the basis for narrow and even sectarian interests. Normally, a third dimension called 'linking' also forms part of social capital, and ideological aspects come into focus here. This dimension includes aspects such as justice, political power and the equitable distribution of income and property. When leadership in Acts is analysed through the lenses of these multi-focal spectacles, interesting perspectives are discovered that can enrich theories on leadership. These discoveries can also open up new perspectives on aspects of being a missional church in our South African context from within the context of Acts.

\section{INTRODUCTION}

The church lost a number of experienced and proven leaders after 1994. This had to happen as the new government needed to round up the handful of skilled people in order to lay the foundation for a new country and a new government. Churches and NGOs had to 'donate' a number of their leaders to political parties, local and national government. If one adds this to the opening up of opportunities for education and jobs in sectors of the economy previously unavailable to the majority of people - then it become [sic] clear how much the church lost.

(Maluleke 2008:8) ${ }^{1}$

Tinyiko Maluleke is the president of the South African Council of Churches and, as a respected theologian and church leader, he has first-hand experience of the church and the role of the churches in post-Apartheid South Africa. With his extensive influence within the churches and South African public life, he lays his finger on the (weak) pulse of the lack of, and need for, spiritual leadership in our country. He does not hesitate to state that we must pay strict attention to the (often cutting) criticism directed openly against the church and her leadership.

We need to hear the message and the message behind the message. As churches, we need to take responsibility not merely for this particular phase in the history of the church, not only for the history of our church denominations; but for both our good and bad legacies.

(Maluleke 2008:5)

The objective of this contribution is to accept the responsibility (with reference to Maluleke), by examining leadership with an imaginary bifocal lens. The focus of a 'short-distance' lens will fall on 'social capital' and the potential role that this can play in the development of spiritual leadership in our young democracy. This concept will be defined and how it could possibly help us to focus even more clearly on the role of faith communities and, in particular, the role of leadership within these communities will be examined.

In view of the concept of social capital, the purpose of the lens for 'distant vision' is to focus on the role of leadership in the earliest Christian faith communities, as recorded in Acts. Here, the focus is specifically on Peter as one of the earliest Christian leaders. We shall thus examine three pericopes in Acts, as three 'moments' in Peter's leadership of this early Christian faith community.

The final section of this contribution contains the notion of bringing together the above-named perceptions and questioning their implications for being a missionary congregation, as well as missionary leadership, particularly in the context of post-Apartheid South Africa; this as a contribution to the responsibility of the leadership in our country, as called for by Maluleke, and specifically the leadership in faith communities.

\section{SOCIAL CAPITAL}

\section{Civil society and social capital}

The notion of social capital ${ }^{2}$ has been around for some time and is a useful lens with which to examine civil society from the angle of 'reclaiming public life'. The World Bank, as well as, inter alia, experts also use this concept in the areas of economic and societal development as a way of discovering how development takes place in organisations. It is obvious that faith communities are important sources of social capital in community development and regeneration. In South Africa, the government has used

1.De Gruchy and Ellis (2008:9) talk about 'Christian leadership in "another country"' when they describe the situation: 'This intensive engagement with the context of apartheid was the great strength of Christian witness in South Africa; but it has also proved to embrace a serious weakness. As the context changed so radically ... we woke up in "another country" in which the politics of "apartheid" had dissolved so quickly, weakening the ability of the Church to engage with public discourse on social themes.

2.'The term 'social capital' is sometimes distrusted because it seems to impose a utilitarian economic language on human relationships. It is also seen as linked to a community and social-order agenda which many question. Rather like the notion of 'community,' it is also hide a negative, destructive side. However, social capital is not bound inevitably to a particular economic theory or political standpoint. It is a means to expand our understanding of how people can be advantaged (or indeed disadvantaged) by their social networks as well as by their physical and human capital. In particular, the distinctions between bonding, bridging and linking social capital can be used to develop a closer, critical exploration of community networks, the resources they offer, and the constraints they impose' (Furbey et al. 2006).

.


this concept at national and provincial levels to address societal and community development. ${ }^{3}$

Social capital is normally associated with the work of Jane Jacobs (1961), in relation to urban life and neighbourliness; of Pierre Bourdieu (1986), with regard to social theory; of James S. Coleman (1988), regarding the social context of education; and of Robert D. Putnam $(1993,2000)$ who launched social capital as a popular focus for research and policy discussion. Putnam introduces the idea as follows:

Whereas physical capital refers to physical objects and human capital refers to the properties of individuals, social capital refers to connections among individuals - social networks and the norms of reciprocity and trustworthiness that arise from them. In that sense social capital is closely related to what some have called 'civic virtue.' The difference is that 'social capital' calls attention to the fact that civic virtue is most powerful when embedded in a sense network of reciprocal social relations. A society of many virtuous but isolated individuals is not necessarily rich in social capital.

(Putnam 2000:19)

According to the Social Capital Formation Document of the Western Cape Provincial Department of Social Services and Poverty Alleviation,

social capital refers to the strengthening and establishment of networks, relationships, norms and values that contribute to the building of social cohesion, racial integration and the strengthening of a social safety net during times of crisis (economic, natural, and other). It is not an end in itself, but a means to an end.

(Department of Social Services and Poverty Alleviation 2005:23)

In general, three types of social capital can be distinguished.

Bacon explains these types as follows:

Bonding social capital is characterized by strong bonds like those between family members or members of an ethnic group. Bridging social capital designates weaker, less dense but more crosscutting ties like those between business associates, acquaintances, friends from different ethnic groups. Linking social capital refers to connections between people at different levels of power or social status. The capacity of individuals and communities to access resources, ideas and information from formal institutions beyond the immediate community radius could be said to depend upon linking social capital (my italics).

(Bacon 2002:5)

\section{Faith communities and social capital}

Ammerman (1999) uses the distinctions of social capital by applying them specifically to faith communities. ${ }^{4}$ Together with a few colleagues, she did research in 23 congregations in the USA. This research focused on the impact of social change and the transformation of congregations, and vice versa, thus on the impact that faith communities possibly have on society. In this regard she arrives at the following conclusion:

The social processes of community formation govern the rise and fall of congregations, and the spiritual energies generated in congregations help to shape the social structures of community.

(Ammerman 1999:2-3)

Ammerman (1999:342) defines social capital within this context as 'those connections of communication and trust that make the organization of a complex society possible'. She then continues to pay particular attention to the question: What type or quality of social capital do congregations generate and do these forms of social capital differ in any way from those that other voluntary organisations generate? Her conclusion is that there is no dramatic difference, but that congregations indeed have certain identifications that promote a 'sense of belonging' (see 'bonding' above). Here, relations of trust develop that, in turn, contribute

3.See the document of the Department of Social Services and Poverty Alleviation (2005) in the Western Cape, 'Social capital formation document'.

4.In this respect, also compare Wepener and Cilliers (2006). towards communication and the coordination of the activities in a community that, in this way, contribute towards the wellbeing of the community (see 'bridging' above). Individuals and communities both benefit from this on the basis of a certain 'legitimacy' received, which means that they enjoy a certain status and recognition (Ammerman 1999:363).

Furthermore, Ammerman (1999:364) believes that faith communities also contribute towards the development of what she calls 'civil know-how', which she refers to as 'civic capital'. The latter can be viewed as an arsenal of skills and even networks for a community's political life. This 'civil knowhow' is nothing but the 'linking social capital' referred to above. Woolcock's (2001:3) definition sums this concept up as follows: 'Linking social capital, (is the kind of social capital) which reaches out to unlike people in dissimilar situations, such as those who are entirely outside of the community, thus enabling members to leverage a far wider range of resources than are available in the community' (Italics IN).

The above distinction (bonding, bridging and linking) is especially important when we reflect upon the leadership in communities and congregations. This distinction is further emphasised when Ammerman (1999:365) writes that faith communities still produce two elements: 1 ) the 'social' capital of association (bonding and bridging); and 2) the 'civil' capital of communication and organisational skills (linking). In a special way, these aspects often become visible within communities in times of crisis.

To finally cleanse the lens of social capital before paying attention to leadership, the three aspects of social capital can be summarised as follows:

- bonding social capital - refers to the (strong) horizontal bonds that exist between people who find themselves in similar situations - such as immediate relatives, close friends, neighbours or even members of a congregation

- bridging social capital - refers to the (weaker) horizontal bonds that exist between people who find themselves in similar situations, but which could be cross-cultural - such as acquaintances, partners or colleagues at work and loose friendships, which could also include people of other ethnic groups

- linking social capital - refers to the (potential) vertical bonds that exist between people who do not find themselves in similar situations (thus, people whose status and power in the community differ) and who exist outside their immediate communities, but who provide a much larger arsenal of sources for local communities - such as local and national political structures. In faith communities this could include synodical structures and Church Councils (national and international).

With this lens that, like a prism, divides the light into three rays (bonding, bridging and linking), we shall now pay attention to a few aspects of leadership.

\section{LEADERSHIP}

Three forms of leadership are often distinguished in theories on leadership, ${ }^{5}$ with the first being task leadership. This is the ability that leaders develop to perform certain roles successfully in organisations. In respect of churches and congregations, this is the role that leaders play, for example, to lead a worship service, proclaim the Word, instruct members, establish a small group, practise pastoral care, chair meetings, and visit congregants in hospital. Being equipped and being aware that one is called to fulfil these different roles is an important part of leadership and can be regarded as the proverbial 'business as usual'. A large part of theological training is about preparing students to fulfil these different roles with the necessary knowledge, attitudes and

5.In this regard, compare, inter alia, the works of Burns (1978), Hackman and Johnson (1996), Burke (2002), Quinn (2004), and Bass and Osmer (2008). 
skills within a variety of faith communities. In terms of social capital, task leadership concerns 'bonding' challenges, which entails paying attention in various ways to the building of close bonds that are based on mutual faith convictions (theological studies and creeds), where the articulation of the vision for faith communities takes place.

The second form of leadership is transactional leadership, which consists of reciprocity, that is, where I can do something for another and he/she reciprocates. This is a 'trans-act' or reciprocal act of giving and receiving. According to Osmer, this takes place in two basic ways in the leadership of organisations:

(1) meeting the needs of those involved in an organization in return for their contribution to the organization, and (2) making political trade-offs to deal with competing agendas of different coalitions in an organization so it can best accomplish its purpose.

(Osmer 2008:176)

Within faith communities, this form of leadership cannot be enforced by means of a contract. It often depends on people's willingness to become involved. Leaders in faith communities often attain people's support by reacting to their needs or requirements, and then offering the members an opportunity to participate in activities, make friends, become part of the community and help to establish koinonia. In congregations, leaders participate in a variety of ways in various 'trans-actions'. This may be in the form of instructions in faith to children, where parents want their children to learn the basic truths of the faith, or in the form of small groups where people have a need to share their faith with others at a more intimate level. The leaders hope that, in reaction, the members will support the congregation with their thanks-offerings and volunteer to participate in the various activities (Osmer 2008:177).

In my opinion, a further important part of this leadership concerns the challenge to establish 'trans-actions' with other faith communities in the area; that is, a horizontal challenge to start 'bridging' through ecumenical bonds with believers from other denominations and socio-cultural backgrounds. This asks special demands from leadership, as it often requires people to be taken outside their 'comfort zones'. Within our own context, examples include 'healing-of-memories' workshops that are offered for members from various congregational backgrounds.

The third form of leadership is transformation leadership, which is about 'deep change' (Quinn 2004:200), and is related to the leading of an organisation by a process in which identity, mission and culture are fundamentally transformed. Within a congregational context, this is about the transformation of worship and fellowship, reaching out and offering hospitality to new members who are different. It concerns developing a vision of what the congregation can become and the mobilisation of followers who are willing to subscribe to this vision.

To lead this type of 'deep transformation' can be risky, and it demands much effort. This type of transformation requires the sound distinction of the key values and most profound convictions of an organisation. There must be honest examination of activities that could be hypocritical and that do not truly reflect the values of the organisation with integrity. This type of transformation is often resisted by the core group who are at risk of losing their power and their control of the organisation. Therefore, profound transformation often is a quite nasty affair that does not unfold rationally or according to the rules. In the interim period, when there is a realisation that the earlier modus operandi is outdated but new plans are not yet operational, there often is a sense of chaos. This period is then characterised by conflict, dissatisfaction and failure (Quinn 2004:201).

At the deeper levels of culture, vision and mission, part of this transformation generally also entails transformations that are necessary at other levels within a community. ${ }^{6}$ Political, social and economic structures often play an important role in the transformation of communities (see Ammerman's work mentioned above). It requires leadership to cultivate the 'vertical bonds' of 'linking social capital' within a community where sources are available that enable local communities to address problems such as drug abuse and HIV/Aids as part of the transformation of faith communities.

In summary, Osmer (2008:178) provides a brief description of the three forms of leadership:

- Task competence: Performing the leadership tasks of a role in an organisation well.

- Transactional leadership: Influencing others through a process of trade-offs.

- Transforming leadership: Leading an organisation through a process of 'deep change' in its identity, mission, culture, and operating procedures.

Furthermore, Osmer (2008:179) is of the opinion that these three forms of leadership are all necessary in faith communities, but that today, especially in the mainstream Protestant churches, the greatest need is for transformation leadership. Therefore, it is clear from the above discussion that 'bonding social capital' can be linked to task leadership, while 'bridging social capital' can be connected directly to transactional leadership and 'linking social capital' can relate to transformation leadership.

However, neither of these forms of leadership can succeed if the 'moral formation' of leadership is not taken into account. Kretzschmar (2007:18-36) places the formation of moral leaders in our Southern African context within a Christian moral framework and, in her opinion, at least five types of 'conversions' are necessary for the moral formation of character in leadership, namely the conversion of the mind, heart, will, relations and actions of leaders.

\section{LEADERSHIP IN ACTS}

To give justice to leadership in Acts within the confines of an article such as this is virtually impossible. ${ }^{7}$ Therefore, in this section we shall concentrate mainly on aspects of Peter's leadership in Acts 1:12-26, 10-11 and 15. The aim is to examine three 'moments' of leadership in an attempt to ask whether the lenses of social capital and leadership could indeed teach us something of being a missionary church in Acts.

I am acutely aware of the dangers of comparing models of leadership from a modern (especially Western) paradigm of leadership to those in Acts, without taking into account the huge historical and cultural differences between a 1st century Mediterranean culture and our modern culture. Together with Robertson (2005:276), I am of the opinion, however, that models and approaches from the social sciences do not offer new answers to old questions as much as they suggest a new level of questioning. New paradigmatic queries can then be explored through more traditional forms of exegetical analysis. We therefore can examine how these three passages can help to open some new perspectives on missional leadership by making use of the social capital and leadership lenses.

\section{Acts 1:15-26}

In the Biblical stories, symbols are important, as they function as theological markers for the readers. In this respect, there is hardly a more important symbol than that of the 12 , which naturally symbolise Israel as God's people. The meaning of 12 apostles has special prominence in Acts, as the restoration of

6.See, for example, MacMaster's (2007) discussion of gangsterism on the Cape Flats.

7. See the contribution of Robertson (2005.273), in which he points out the role of the See the contribution of Robertson (2005:273), in which he points out the role of the
twelve, the seventy and the seven as groups who functioned as leaders at different twelve, the seventy and the seven as groups who functioned as leaders at different stages in Acts. By making use of a 'systems approach' he help to open up a different
understanding of leadership in the early church, which at the same time raises quesunderstanding of leadership in the early church, which at the same time raises ques-
tions that bear on tensions in the authority and leadership of the church today. 
Israel, according to Luke, forms part of the role (or task) of these 12 apostles. The re-establishment of the group's original number also allows the light to fall on their role as agents of God's plan for the restoration of the 'twelve tribes of Israel' (Wall 2002:47).

In this respect, we cannot but take note of Peter's leadership role early in Acts, together with the ironic parallel in both his and Judas's failures as described in the gospels. However, the difference is that, where Judas was full of shame about his betrayal and turned into himself, we find that Peter's remorse allowed him to return to Jesus and the faith community, where he received forgiveness. By this strategic placement of these events, Luke points out the theological meaning of Judas's betrayal as more than a mere failure of a single disciple, but also how Judas's action represents danger for the survival of the whole faith community (Wall 2002:48-49).

In contrast, we find the reaction of Peter, who, as a reinstated member of the community, now comes forward as a leader and interpreter of the events. In this, his first speech (Ac 1:16-22), which is followed by several others in Acts, he takes responsibility for especially two tasks. Firstly, with the assistance of the authority of the Scriptures, he points out the 'need' (dei) of the fulfilment that David predicted as part of God's plan. Judas's tragic story is then related here. This clarifies that the Spirit-filled (re)interpretation of the Scriptures' prophesies, as part of God's aim and as the interpretation of the meaning thereof for the faith community, formed the primary and most important aspect of Peter's leadership role (Tannehill 1990:20).

The second task for which Peter accepts responsibility is to appoint somebody in Judas's place: 'May another take his place of leadership' (Ac 1:20b). In the second part of his speech (Ac $1: 20 b-22)$, we find an exposition of the prerequisites required of Judas's substitute. We also see how the whole community is involved in this decision-making process. Firstly, they ask God's guidance and then they cast the lot, upon which Matthias was elected as the 12th apostle (Johnson 1992:36).

When looking through the lenses of social capital and leadership, one recognises aspects of 'bonding capital' and 'task leadership' in Peter's actions. Here, as the interpreter of the faith community, Peter articulates God's plan for them and finds this in the Spirit-filled re-interpretation of the tradition within new circumstances. God's plan for the restoration of Israel goes ahead and this plan begins with him who betrayed Jesus, but who returned remorseful and who was reconciled with God and the faith community again.

Thus, Peter's task is that of discernment, in which, guided by the Spirit, he led the faith community in a decision-making process in which the Scriptures (Ac 1:20), an intimate relation with Jesus (Ac 1:21-22) and prayer (Ac 1:24-25) played a central role. All these acts form part of 'bonding capital' to form the horizontal bonds of the community by attaining clarity about their identity as part of God's chosen people.

\section{Acts 10-11}

In Acts 10-11 we find the conversion of Cornelius in the second Lukan volume (Acts) as the central occurrence. The acceptance of this uncircumcised Gentile within the Christian circle of believers leads, as it were, to a second Pentecostal happening. According to Acts 10:44-48, the Spirit of the Lord is poured onto even a Gentile and his family (Bosch 1992:114). Johnson describes this event as follows:

After the interlude devoted to the call of Saul who would be the elect vessel for carrying the name to the Gentiles (9:1-30), Luke again showed the work of Peter in Judea, healing the lame, raising the dead, and at the same time moving geographically and ethnically closer to the edge, to the place by the sea in Joppa, where he resided with the ritually impure tanner Simon, ready to hear the call from the Gentile city of Caesarea (9:31-42). Now at last Luke is ready to show how the Church made this most fundamental and dangerous step, which would involve the greatest struggle and demand the most fundamental self-reinterpretation for the nascent messianic movement, which in fact would in principle establish its identity as universal and not simply ethnic religion.

(Johnson 1992:37)

According to Bevans and Schroeder (2006:23-24), Acts 10:1-11:18 (Cornelius and his household) already forms the fifth stage in the seven stages of mission that they distinguish in Acts. We find the culmination of these events in Acts 10:34-48: Peter's speech at Cornelius' home, when he begins with the following words: 'I now realize how true it is that God does not show favouritism but accepts men from every nation who fear him and do what is right' (Ac 10:34-35). With these opening words he testifies about his own 'conversion' that took place shortly before: 'But God has shown me that I should not call any man impure or unclean' (Ac 10:28). This divine revelation leads to Peter's missionary activities outside Jerusalem's borders and also wider than the people of Israel. Now, the full implication of this mission had become clear to him. God does not distinguish on the basis of ethnicity, but on the grounds of faith. Thus, God accepts people from all nations who worship him and do what is right (Ac 10:35; Wall 2002:167)

To read how Peter was confronted with resistance when he returned to Jerusalem is interesting. 'So when Peter went up to Jerusalem, the circumcised believers criticized him and said, "You went into the house of uncircumcised men and ate with them" (Ac 11:2). After Peter's testimony about what had happened, they were satisfied and it seems that they enthusiastically made this new insight part of their lives: 'When they heard this, they had no further objections and praised God, saying, "So then, God has granted even the Gentiles repentance unto life"' (Ac 11:18).

Now, when we draw the lenses of social capital and leadership closer, one recognises the bridging elements that are at issue here. These are the (weaker) horizontal bonds that exist between people who find themselves in similar situations but are crosscultural. On the grounds of inner conviction (conversion), Peter succeeds in overstepping the Jewish and Gentile boundaries, thus bringing about 'bridging' and binding the Jewish believers cross-culturally to other believers.

When examining how Peter set to work it is possible to recognise aspects of transactional leadership. It is also clear that Peter definitely influenced his co-Jewish believers and that, by means of 'trans-actions', he led them to new insights. Thus, a broadening of their understanding of God takes place and, simultaneously, a broadening of their own identity. But, as Johnson points out above, it was a dangerous step that did not take place without conflict, as this demanded a fundamental re-interpretation of this Messianic group's identity. Therefore, transactional leadership requires knowledge, skills and attitudes other than task leadership.

\section{Acts 15:1-35}

Both Johnson (1992:268) and Wilson (2006:192) regard Luke's description of the meeting in Jerusalem as a 'watershed' in the theological history of Acts. These cardinal moments in the history of the early church's development of self-comprehension are described in concise and rich theological terms. After several people, previously Pharisees, raised the problem related to the circumcision of the converted Gentiles (15:5), the leadership met. After lengthy debates by the core group, including Peter, Barnabas and Paul, they began testifying about their own experiences. We find the consequences of this in Acts 15:7-11, where Peter stood up and addressed the meeting. His final conclusion was: 'No! We ... believe that we are saved only by the grace of the Lord Jesus' (Bevans \& Schroeder 2006:28-29).

During the further course of the meeting, one notes how Barnabas and Paul (Ac 15:12) had the opportunity to speak, and later also James (Ac 15:13), who contributed meaningfully. 
From Acts 15:22 we discover that the resolution of the entire meeting boiled down to the fact that a deputation would be sent to Antioch with a letter explaining the situation. In summary, Johnson regards the Jerusalem meeting as a 'theological process' in which the church had to decide about her identity as God's people. Therefore, it was a process that was characterised by dialogue and conflict (Johnson 1983:86-87).

When we look through the lenses of social capital and leadership, we reach the point that 'linking capital', together with 'transformative leadership', offers valuable insights. In Acts 15 it is clear that the events in Antioch gave rise to the need for contributions and counsel from a 'vertical' relation, from which 'other sources' could be drawn to solve the problem. We see this in the way in which the believers in Antioch looked to Jerusalem for guidance and leadership and how, through a process of dialogue, a resolution was reached that had definite implications for believers in both Antioch and Jerusalem (Wall 2002:210).

Naturally, a further 'vertical' source that could be investigated here is tradition. This is evident in Simon's long citation, which refers to the prophets (Ac 15:15-17) as the authoritative source and motivation for his argument. But, peculiar to transformation, this vertical source cannot be limited to talks and citations; action must take place. So, Peter and his co-leaders proposed a process that could introduce this transformation, which would be initiated by the deputation visiting Antioch by means of a letter as a document in support of this process. In Acts 15:31 we read how this process of consultation had the required result and how, from here, the process of transformation would gain ever more momentum.

\section{The role of the Holy Spirit}

The lenses of social capital and leadership should not deter us from focusing further and deeper. This focus namely is on the role and work of the Spirit in each of the scriptural pericopes that we examined. In these pericopes, we read how the Spirit actually enables and energises every form of 'social capital' and leadership (see Ac 1:16, 10:46, 15:8, and 15:28). Even the role that the church plays in this respect may not blind us to the work of the Spirit. In this regard, Newbegin states that

the Spirit who thus bears witness in the life of the Church to the purpose of the Father is not confined within the limits of the Church. It is the clear teaching of the Acts of the Apostles, as it is the experience of missionaries, that the Spirit goes, so to speak, ahead of the Church.

(Newbegin 1964:59)

Bosch (1991:189) distinguishes the Lukan missionary paradigm from that of Matthew and Paul and believes that these paradigms form sub-paradigms of a coherent Christian missionary paradigm. Characteristic of this Lukan paradigm is, inter alia, the ministry and role of the Holy Spirit, the role of the confession of guilt and forgiveness, prayer, love and acceptance of the enemy. This brings us to the final matter to be focused upon, which concerns perspectives on missionary leadership.

\section{LEADERSHIP FROM A MISSIONAL PERSPECTIVE}

The objective of this final section is to place social capital, leadership and Peter's leadership in Acts within a missionary paradigm. 'Missionary ecclesiology' is a term used to point out that the being or nature of the church is missional and that the mission of the church is not but 'one of' the church's tasks or assignments. Since 1993, we find this emphasis very strongly in the World Council of Churches, with its focus on the intimate bond that exists between koinonia, mutual confession, testimony, mission and evangelisation. ${ }^{8}$

8.See Towards koinonia in faith, life and witness (The Dublin Paper), Fifth World Conference on Faith and Order (Geneva, Switzerland: WCC Publications, 1993), 18.2.1.
It is widely acknowledged that two theologians in particular were at the forefront of making the church and theology aware of this missionary challenge, namely Dawid Bosch (1991) and Lesslie Newbegin (1992). In the recent publication of Van Gelder (2007:121), written from the 'missional paradigm', he explains that 'the missional church is missionary by nature - the church is. In living in the world, the missional church engages in ministry that is consistent with its nature - the church does what it is. Finally, the missional church seeks to bring order and organization to these activities - the church organizes what it does'.

Upon examination of missional leadership, it is clear that Guder (1998) and others are convinced that leadership is the key for the formation of missional communities. 'The Spirit empowers the church for mission through the gifts of the people. Leadership is a critical gift, provided by the Spirit because, as the Scripture demonstrates, fundamental change in any body of people requires leaders capable of transforming lives and being transformed themselves' (Guder 1998:133).

The question is, what does this kind of (transformative) leadership and organisation look like? Van Gelder (2007:122) explores this kind of leadership from three different sources of information in seeking to engage the dynamics of a changing context: (1) biblical materials, (2) historical polities, and (3) social science insights. According to him it is important to realise that each source makes a significant contribution to the whole (Van Gelder 2007:122).

The earlier discussion on 'social capital and leadership' was a perspective from the third source, while the comments on 'leadership in Acts' were from the first source. The second source, historical polities, normally involves forms of polity that developed within theological traditions over the centuries.

The development of these polity traditions over the centuries makes it difficult to go back into the New Testament without bias ... power gets institutionalized within structure, and once structure is in place it is quite difficult to reform.

(Van Gelder 2007:122)

Here is not the time and place to go deeper into the important role and function of historical polities. Suffice it to say that they bring with them an identity, ministry and organisation that are important sources of information, both in the forming and reforming of the church in new situations. However, it is important for leaders in faith communities to realise that all three types of social capital formation do need attention within a missional context. To concentrate only on bonding without attention to the other, the core leadership group can become stagnate and sectarian. To concentrate only on bridging without taking the other into account, the leaders can become disconnected and powerless. To concentrate only on linking, leaders can lose the core group's interest and end up without support, community and identity.

The same is true concerning the three mentioned aspects of leadership. You need to concentrate on all three, realising that the second and third forms of leadership take a special effort and need the development of knowledge, skills and attitudes that differ from the daily tasks of ministry 'as usual'. To become a missional church, nothing less than 'deep change' is necessary. Peter's leadership in Acts showed that it is not an easy task to take people across boundaries of race and ethnicity.

\section{CONCLUSION}

Let us return to the challenge set out at the start that Tinyiko Maluleke poses to the leadership of the church in the South African context. With the different biblical, historical and social sciences perspectives in mind, the purpose of the article is to encourage Christian leaders to take up the missional challenge of 'bonding, bridging and linking social capital' through 'tasks, transactions and transformative actions' in the way that Peter operated in the early faith communities in Acts. But what would 
this 'missional challenge' look like within our South African context?

De Gruchy and Ellis (2008:18-20) are of the opinion that we need to pay attention to the issues of power, collaboration and pedagogy if we are concerned about future leadership in our specific context. The question of power deals with relationships in terms of key factors like race, age, gender, nationality language and professional status. Because our individual lives are embedded in wider social narratives, we carry power (or the lack of it) into any relationship and these can be a hindrance in the empowering of the next generation of leaders.

The second aspect, collaboration, is equally important in developing the next generation of Christian leaders. Because we are living in a very individualistic and competitive culture, we often tend to focus on career development and promotion at the cost of others. Such an approach does not help the next generation of leaders. We need to develop models of team work, peer support and collaboration in mutual capacity building.

Thirdly, we have to focus on a dialogical pedagogy in the spirit of Paulo Freire, where we are concerned about the wisdom of ordinary people. In this sense, leadership is interested in the wisdom of the whole team and not just that of the current leaders. In other words, the 'teachers' need to learn and the learners need to teach through conversation and dialogue. It is not difficult to see in what ways these three pedagogical challenges can inform missional leadership that seeks to empower the church for mission through the gifts of the people; gifts that are capable of transforming people's lives and being transformed themselves.

Again taking into account Maluleke's remark that the churches lost leadership to political parties, local and national government and many other places, we must also not lose sight of the potential of these leaders to exercise ethical leadership in their new positions of power. If we are serious about 'linking social capital', they provide excellent resources for 'vertical' relationships.

As leaders we take up these challenges, in the last instance, with the realisation that none of these activities will bear any 'missional fruit' or transform God's people if we lose sight of the 'theological perspective'. The focal point of the theological perspective is that the Holy Spirit has been poured out on the day of Pentecost on all people to empower the ministry of the missional church as a community led by the Spirit.

\section{REFERENCES}

Ammerman, N., 1999, Congregation and community, Rutgers University Press, New Brunswick.

Ammerman, N., 2005, Pillars of Faith: American Congregations and Their Partners, University of California Press, Berkeley.

Bacon, D., 2002, 'Revitalising civil society through social capital formation in faith based organizations: research findings from Northern Ireland', paper presented at the fifth conference of the International Society for Third Sector Research, University of Cape Town, Cape Town, 9-11 February.

Bevans, S. \&. Schroeder, R.P., 2006, Constants in context: a theology of mission for today, Orbis Books, Maryknoll.

Bosch, D., 1991, Transforming mission: paradigm shifts in theology of mission, Orbis Books, Maryknoll.

Bourdieu, P., 1986, The forms of capital, in J. Richardson (ed.), Handbook of Theory and Research for the Sociology of Education, 241-258, Greenwald Press, New York.

Burke, W., 2002, Organization change: Theory and practice, Sage, Thousand Oaks.

Burns, J., 1978, Leadership, Harper \& Row, New York.

Cilliers, J. \&. Wepener, C., 2007, 'Ritual and the Generation of Social Capital in Contexts of Poverty: A South African Experience', International Journal of Practical Theology 11, 39-55.
Coleman, J., 1988, 'Social capital in the creation of human capital', American Journal of Sociology 94, 95-120.

De Gruchy, S. \&. Ellis, W., 2008, 'Christian leadership in "another country": Contributing to an ethical development agenda in South Africa today', in S. de Gruchy, N. Koopman \& S. Strijbos, From our side: Emerging perspectives on development and ethics, pp. 9-20, Rozenburg Publishers, Amsterdam.

Department of Social Services and Poverty Alleviation, 2005, 'Social Capital Formation Document', Document presented at workshop hosted by the University of the Western Cape's Economics Department in partnership with the Western Cape Provincial Department of Social Services and Poverty Alleviation, 9-10 February 2005.

Fukuyama, F., 2001, 'Social Capital, Civil Society and Development', Third World Quarterly 22(1), 7-20.

Gomulia, C., 2006, 'State-society networks: A case of political participation in the Western Cape Province, South Africa', Cape Town, unpublished, p. 9.

Gonzales, J., 2001, Acts: The Gospel of the Spirit, Eerdmans, Grand Rapids.

Guder, D. (ed.), 1998, Missional church: A vision for the sending of the church in North America, Eerdmans, Grand Rapids.

Hackman, M., 1996, Leadership: A communication perspective, Waveland Press, Prospect Heights.

Heitink, G., 1999, Practical Theology: History, Theory, Action Domains: Manual for Practical Theology, Eerdmans, Grand Rapids.

Jacobs, J., 1961, The death and life of great American cities, Random House, New York.

Johnson, L., 1983, Decision making in the church, Fortress Press, Philadelphia.

Johnson, L., 1992, Sacra Pagina: The Acts of the Apostles, The Liturgical Press, Collegeville.

Kärkkäinen, V.-M. 2002. An Introduction to Ecclesiology: Ecumenical, Historical \& Global Perspectives, InterVarsity Press, Downers Grove.

Kretzschmar, L., 2007, ‘The formation of moral leaders in South Africa: A Christian-ethical analysis of some essential elements', Journal of Theology for Southern Africa 128, 18-36.

MacMaster, L., 2007, 'Resilience of faith communities on the Cape Flats. South Africa - a pastoral theological perspective', paper presented at the 8th World Congress of the International Council on Pastoral Care and Counselling (ICPCC), Krzyzowa, Poland 7-14 August 2007.

Maluleke, T., 2008, 'A postcolonial (South) African church Problems and promises', paper presented at the annual Desmond Tutu Lecture at the University of the Western Cape, Bellville, 10 April 2008.

Newbegin, L., 1964, Trinitarian faith and today's mission, John Knox Press, Louisville.

Newbegin, L., 1992, 'The logic of mission', in Scherer, A. \& Bevans, S.B., New directions in mission and evangelization, Orbis Books, Maryknoll.

Osmer, R., 2008, Practical theology: An introduction, Eerdmans, Grand Rapids.

Pelikan, J., 2005, Acts, Brazos Press, Grand Rapids.

Putnam, R., 1993, 'The prosperous community: Social capital and public life', The American Prospect 4, 13-24.

Putnam, R., 2000, Bowling alone. The collapse and revival of American community, Simon \& Schuster, New York.

Putnam, R. \&. Feldstein, L.M., 2003, Better Together: Restoring the American Community, Simon \& Schuster, New York.

Quinn, R., 2004, Building the bridges as you walk on them, Jossey Bass, San Francisco.

Robertson, C., 2005, 'The limits of leadership: challenges to apostolic homeostasis in Luke-Acts', Anglican Theological Review 87(2), 273-290.

Tannehill, R., 1990, The Acts of the Apostles. Vol. 2 of The narrative unity of Luke-Acts: A literary interpretation, Fortress Press, Minneapolis.

Van Gelder, C., 2007, The ministry of the missional church: A community led by the Spirit, Baker Books, Grand Rapids. 
Wall, R., 2002, The Acts of the Apostles: introduction, commentary, and reflections. The new interpreter's Bible: A commentary in twelve volumes, Abingdon Press, Nashville.

Wepener, C. \& Cilliers, J., 2006, 'Research on liturgy and the generation of social capital in contexts of poverty: A theoretical departure', Ned Geref Teologiese Tydskrif 47(3\&4), 786-798.
Wilson, S., 2006, The Gentiles and the Gentile mission in Luke-Acts, Cambridge University Press, Cambridge.

Woolcock, M., 2001, 'The place of social capital in understanding social and economic outcomes', Isuma: Canadian Journal of Policy Research 2(1), 1-17. 